\title{
1 Efficacy of liquid 1-methylcyclopropene to delay ripening of 'Bartlett' pears
}

2 Sandra Escribano ${ }^{1,3}$, Nobuko Sugimoto ${ }^{1}$, Andrew J. Macnish ${ }^{2}$, William V. Biasi ${ }^{1}$ and Elizabeth J.

3 Mitcham $^{1}$

$4{ }^{1}$ Department of Plant Sciences, University of California, One Shields Avenue, Davis, CA

5 95616, USA. Tel +1-530-752-1826

6 Sandra Escribano: s.escribano@enzazaden.com (corresponding author)

7 Nobuko Sugimoto: sugimot3@gmail.com

8 Andrew J. Macnish: andrew.macnish@ daf.qld.gov.au

$9 \quad$ William V. Biasi: wvbiasi@ucdavis.edu

10 Elizabeth J. Mitcham: ejmitcham@ucdavis.edu

11 Footnotes:

$12{ }^{2}$ Present address: Horticulture and Forestry Science, Queensland Department of Agriculture and

13 Fisheries, Maroochy Research Facility, Nambour, Qld 4560, Australia.

$14{ }^{3}$ Present address: Enza Zaden Research USA, San Juan Bautista, CA 95945, USA

15

16

17

18

(C) 2016. This manuscript version is made available under the Elsevier user license

http://www.elsevier.com/open-access/userlicense/1.0/ 
20 1-Methylcyclopropene (1-MCP) has been a useful tool to extend the postharvest life of 'Bartlett'

21 pears, but fruit response can be highly variable due to competition with ethylene. Application of

22 liquid 1-MCP after harvest was tested to determine its efficacy as compared with gaseous 1-

23 MCP. Fruit harvested from Sacramento and Lakeport, California at early-, mid- and late-

24 commercial harvest maturity were treated with $0.6 \mu \mathrm{L} \mathrm{L}^{-1}$ gaseous $1-\mathrm{MCP}$ at $0{ }^{\circ} \mathrm{C}$ for $24 \mathrm{~h}$ or

25 dipped for $0,15,30,45$ or $60 \mathrm{~s}$ in $250,500,750$ or $1000 \mu \mathrm{g} \mathrm{L} \mathrm{L}^{-1} 1-\mathrm{MCP}$ in four experiments

26 across three years of study. After treatment, pears were exposed to ethylene or kept in cold

27 storage at $1{ }^{\circ} \mathrm{C}$ for 5 weeks before ripening at $20^{\circ} \mathrm{C}$. Treatment with liquid 1-MCP delayed pear

28 ripening as evidenced by delayed softening for a minimum of $6 \mathrm{~d}$ compared to the control fruit,

29 delayed the increase in respiration and ethylene production rates, and reduced respiration and

30 ethylene production rates. Treatment was effective in a concentration- and dip time-dependent

31 manner. Overall, dipping in $1000 \mu \mathrm{g} \mathrm{L}{ }^{-1}$ liquid 1-MCP for $60 \mathrm{~s}$ was the most consistent treatment

32 among years and locations; however, the resulting time to ripen at $20^{\circ} \mathrm{C}$ could be too long for

33 some commercial applications. Treatment at $500 \mu \mathrm{g} \mathrm{L}^{-1}$ liquid 1-MCP is recommended for

34 'Bartlett' pears as this dose controls the ripening process, and provides consistent response for

35 mid- and late-maturity fruit. A postharvest evaluation of a liquid formulation of 1-MCP provided

36 a more consistently effective treatment for 'Bartlett' pears (Pyrus communis) than the current

37 gaseous treatments.

39 Key words: color, ethylene, firmness, 1-MCP, Pyrus communis, respiration 
43 1-Methylcyclopropene (1-MCP) is a well-known inhibitor of ethylene action which has been

44 widely used and evaluated for its capacity to prolong the storage life of many fruits and

45 vegetables (Watkins, 2008). 1-MCP blocks ethylene perception, preventing the signaling

46 mechanism that activates ripening-associated genes (Klee, 2004). Postharvest treatment of

47 European pears with 1-MCP has been shown to decrease fruit respiration rate, ethylene

48 production, softening, ACC synthase and ACC oxidase activities, and development of internal

49 browning and storage scald (Argenta et al., 2003; Baritelle et al., 2001; Calvo and Sozzi, 2004;

50 Hiwasa et al., 2003; Kubo et al., 2003; Ekman et al., 2004; Mwaniki et al., 2005; Trinchero et al., $512004)$.

52 Commercially, 1-MCP is applied to extend the storage life of 'Bartlett' pears, allowing shipment

53 to distant markets. It is usually applied to fruit after harvest in its gaseous form (SmartFresh ${ }^{\mathrm{TM}}$ )

54 inside sealed rooms, containers or tents. However, the fruit response to SmartFresh ${ }^{\mathrm{TM}}$ can vary

55 with season and harvest date (AgroFresh, Inc., personal communication). A number of factors

56 have been shown to influence the success of SmartFresh ${ }^{\mathrm{TM}}$ treatment on pears, including

57 concentration applied, treatment duration, temperature of the fruit during treatment and presence

58 of exogenous ethylene (Argenta et al., 2003; Chen and Spotts, 2005; DeEll et al., 2002; Ekman et

59 al., 2004; DeEll and Ehsani-Moghaddam, 2011; Villalobos Acuña et al., 2011b). Materials in the

60 storage room can reduce treatment efficacy. According to Calvo and Sozzi (2009), treatment of

61 pear fruit with SmartFresh ${ }^{\mathrm{TM}}$ in wooden bins that were wet following hydrocooling was much

62 less effective than treatment of pears in plastic bins. Wet wooden bin material represents a major

63 though unpredictable source of 1-MCP sorption that could bind a significant percentage of the 1- 
64 MCP applied. Recently, Wang and Sugar (2015) reported that pears grown at high elevations, 65 with expected cooler preharvest temperatures, and/or held at $5{ }^{\circ} \mathrm{C}$ for $12 \mathrm{~d}$ between harvest and 1-MCP application frequently showed a reduced response to the treatment.

67 European pears naturally ripen in association with a climacteric rise in ethylene production

68 (Hansen, 1943). 'Bartlett' pears harvested early in the season produce low levels of ethylene at

69 harvest and ripen very slowly or even fail to ripen (Puig et al., 1996; Villalobos-Acuña and

70 Mitcham, 2008). Fruit harvested later in the season produce relatively higher rates of ethylene

71 and ripen more rapidly. In some growing areas, the commercial harvest can take place over a 3 to

724 week period; hence fruit are often picked at different degrees of maturity (Chen and

73 Mellenthin, 1981). To stimulate ripening of early-harvested 'Bartlett' pear fruit that are marketed

74 immediately, treatment with ethylene $\left(100 \mu \mathrm{L} \mathrm{L}^{-1}\right.$ for 1 to $2 \mathrm{~d}$ at $\left.20^{\circ} \mathrm{C}\right)$ and/or exposure to low

75 temperature $\left(0\right.$ to $10{ }^{\circ} \mathrm{C}$ for 5 to $14 \mathrm{~d}$ ) conditioning is used (Agar et al., 2000; Mitcham et al.,

76 2000; Villalobos-Acuña and Mitcham, 2008).

77 Because of the competitive relationship between 1-MCP and ethylene for binding to ethylene

78 receptors (Macnish et al., 2012; Villalobos-Acuña et al., 2011a; Zhang et al., 2009), the efficacy

79 of 1-MCP to delay ethylene-mediated softening of climacteric fruits depends in part on the

80 physiological state of the fruit, with reduced efficacy on more mature fruit (Chiriboga et al.,

81 2013; Gamrasni et al., 2010; Jung and Watkins, 2014; Mir et al., 2001; Wang and Sugar, 2015;

82 Watkins, 2008). The increase in ethylene concentrations within ripening fruit tissues reduces the

83 competitive ability of 1-MCP to bind to available receptors, reducing 1-MCP's effect, while an

84 excess of 1-MCP can lead to failure to ripen (Chen and Spotts, 2005; Ekman et al., 2004; Guillén

85 et al., 2007; Manenoi et al, 2007; Villalobos-Acuña et al., 2011a; Villalobos-Acuña and

86 Mitcham, 2008; Wang and Sugar, 2015; Zhang et al., 2009, 2010, 2011). 
87 Endogenous and exogenous ethylene has been shown to reduce the efficacy of 1-MCP to delay

88 ripening of 'Bartlett' pears (Macnish et al., 2012; Wang and Sugar, 2015). The higher rates of

89 ethylene production at harvest for late season 'Bartlett' pear fruit may explain the failure of 1-

90 MCP treatments to consistently delay fruit ripening (Macnish et al., 2012; Wang and Sugar,

91 2015). This phenomenon has also been described in other fruit, including tomatoes and apples

92 (Macnish et al., 2012; Watkins, 2008; Zhang et al., 2009, 2010, 2011). Zhang et al. (2009, 2010,

93 2011) found that the higher the internal ethylene at the time of tomato treatment with 1-MCP, the

94 smaller the effect on ripening. With apples, Watkins (2008) had earlier suggested the influence

95 of internal ethylene on the inconsistency of 1-MCP treatments. Macnish et al. (2012) illustrated

96 the importance of maintaining the appropriate ratio of 1-MCP to ethylene within the treatment

97 atmosphere. Using 'Bartlett' pears, the authors showed that a relatively high initial 1-MCP:

98 ethylene concentration ratio (e.g., 20-50:1) was necessary for maximum ripening inhibition of

99 early-harvested 'Bartlett' pear fruit. However, this initial ratio did not greatly extend the shelf

100 life of mid- and late-season pears because ethylene produced by these fruit accumulated more

101 substantially during the treatment.

102 These challenges of inconsistent fruit response to SmartFresh ${ }^{\mathrm{TM}}$ applications may potentially be

103 overcome by application of a liquid 1-MCP formulation on the harvested fruit. Such an

104 application would eliminate the need to occupy a sealed room during the 12 or more hours-

105 treatment, and would eliminate the reduction in 1-MCP efficacy due to accumulation of ethylene

106 in the sealed chamber atmosphere during gaseous applications. As discussed by Sisler (2006),

107 Sisler and Serek (2003) and Pongprasert and Srilaong (2014), liquid solutions could facilitate

108 broader agricultural applications. Harvista ${ }^{\mathrm{TM}}$ is a liquid formulation of 1-MCP that was designed

109 as a preharvest treatment to control preharvest drop in apples (Elfving et al., 2007; Yuan and 
110 Carbaugh, 2007). It has also been widely tested as a preharvest treatment to control ethylene-

111 related physiological processes and for its beneficial effects on maturity and postharvest quality

112 of apples (Byers et al., 2005; Defilippi et al., 2010; Elfving et al., 2007; McArtney et al., 2008;

113 Yuan and Carbaugh, 2007) and 'Abate Fetel' (Nock et al., 2009) and 'Bartlett' pears (Villalobos

114 et al., 2010).

115 The use of liquid 1-MCP has recently been evaluated as a postharvest treatment, including as a

116 topical dip in 'Florida' tomato and 'Hass' avocado (Choi and Huber, 2008), 'Sanibel' tomato

117 (Choi et al., 2008) and 'Joanna Red' plums (Manganaris et al., 2008). All of these authors

118 illustrated the potential of this formulation when applied after harvest. In all cases, the

119 formulation delayed ethylene production, the increase in respiration rate, surface color

120 development, and fruit softening. It was also very effective in delaying ripening of fruit

121 harvested at an advanced maturity stage (Manganaris et al., 2008).

122 The principal objective of our study was to assess the postharvest application of a liquid

123 formulation of 1-MCP to provide a more consistently effective postharvest treatment for

124 'Bartlett' pears than the current gaseous treatments. We determined the effects on fruit harvested

125 from two growing locations at early-, mid- and late- commercial harvest maturity within each

126 location. The effects of 1-MCP concentration and dip time on 1-MCP efficacy for different

127 harvest maturities and seasons were tested. 


\section{2.1. Plant material}

133 For three subsequent years (2011 to 2013), mature green, size 110 'Bartlett' pear (Pyrus

134 communis) fruit were obtained on the day of harvest in packed boxes from packinghouses near

135 Sacramento and Lakeport, California. The fruit were sampled near the time of the first

136 commercial harvest and then every 5 to $8 \mathrm{~d}$ during the season to capture three stages of maturity

137 from each growing region. All fruit were transported to the University of California, Davis in an 138 air-conditioned vehicle. Upon arrival to the laboratory, the fruit were examined to eliminate

139 damaged fruit, and selected for uniform quality and absence of sunburn, bruises or cuts. Fruit for 140 each experiment were randomly divided into mesh bags for the following liquid or gaseous 1-

141 MCP treatments.

\section{$142 \quad$ 2.2. 1-MCP treatments}

\section{$143 \quad$ 2.2.1. Experiment 1: gaseous versus liquid 1-MCP}

144 In 2011, an initial comparison was made between gaseous and liquid 1-MCP in fruit harvested in 145 Sacramento and Lakeport. The fruit were divided into three subsets of 150 fruit. One subset of 146 fruit from each harvest was cooled to $0{ }^{\circ} \mathrm{C}$ overnight and treated with $0.6 \mu \mathrm{L} \mathrm{L}^{-1}$ gaseous 1 -MCP

147 at $0{ }^{\circ} \mathrm{C}$ for $24 \mathrm{~h}$. A second subset was dipped for $1 \mathrm{~min}$ in $1000 \mu \mathrm{g} \mathrm{L}{ }^{-1} 1-\mathrm{MCP}$ solution at an 148 ambient temperature of $29-38^{\circ} \mathrm{C}$ in a $37.8 \mathrm{~L}$ container. The concentration of liquid 1-MCP was 149 selected to provide a similar dose of $1-\mathrm{MCP}$ as the gaseous treatment, based on advice from the 150 manufacturer, AgroFresh, Inc. Solutions were prepared from formulation AFxRD-038 (3.8\%

151 active ingredient, AgroFresh, Inc., Yakima, WA). The desired level of active ingredient ( $0.263 \mathrm{~g}$

$\left.152 \mathrm{~L}^{-1}\right)$ was suspended in $10 \mathrm{~L}$ of distilled water and a surfactant (Nu-Film P, 0.1\%, Miller Chemical 
$153 \&$ Fertilizer Corp., Hanover, PA, USA) for maximum absorption. The mixture was stirred gently 154 to avoid off-gassing until complete dissolution of the powder. The solutions were used no later 155 than 15 min after preparation, and all immersion treatments were completed within 10 min. Fruit 156 were immersed into the solutions ensuring complete coverage of the fruit during the immersion 157 period. The third subset of fruit was dipped in distilled water with the surfactant (Nu-Film P,

$1580.1 \%$ ) as an untreated control. After removal, fruit were air dried at $20 \pm 2{ }^{\circ} \mathrm{C}$, packed back into 159 vented boxes, and placed at $20^{\circ} \mathrm{C},>95 \% \mathrm{RH}$ overnight.

160 Two boxes of 75 fruit each were used for each treatment; one box from each treatment was then

161 exposed to $100 \mu \mathrm{L} \mathrm{L}^{-1}$ ethylene for 24 hours at $20^{\circ} \mathrm{C}$, a standard treatment for fruit ripened 162 immediately after harvest. After the ethylene treatment, fruit were maintained at $20{ }^{\circ} \mathrm{C}$ for 163 ripening evaluation. The second box from each treatment was stored at $1{ }^{\circ} \mathrm{C}$ for 5 weeks to 164 simulate shipment and/or storage before being transferred to $20^{\circ} \mathrm{C}$ for ripening.

\subsubsection{Experiment 2: liquid 1-MCP concentration}

166 In 2012, we studied the effect of 1-MCP concentration in the liquid formulation on its efficacy.

167 Fruit from early-, mid- and late-harvest maturity in Sacramento and early-harvest in Lakeport

168 were immersed for $60 \mathrm{~s}$ in $0,250,500,750$, or $1000 \mu \mathrm{g} \mathrm{L}{ }^{-1}$ liquid 1-MCP. Solutions were

169 prepared as described for experiment 1 , with the corresponding levels of active ingredient $(0$,

$1700.066,0.132,0.197$ and $0.263 \mathrm{~g} \mathrm{~L}^{-1}$, respectively). After treatment, fruit were maintained at 20

$171{ }^{\circ} \mathrm{C}$ for ripening and evaluation. No fruit were stored.

\section{2.2.3. Experiment 3: liquid 1-MCP dip time}


173 In 2012, mid- and late-harvested pear fruit from Lakeport were immersed in $250 \mu \mathrm{g} \mathrm{L}{ }^{-1}$ for 0,15 ,

17430,45 , or $60 \mathrm{~s}$. After treatment, fruit were kept at $20^{\circ} \mathrm{C}$ for ripening assessment. No fruit were

175 stored.

176 2.2.4. Experiment 4: interaction between liquid 1-MCP concentration and dip time

177 In 2013, early-, mid-, and late-harvested fruit from Sacramento and Lakeport were treated with 0,

178250,500 , or $1000 \mu \mathrm{g} \mathrm{L} \mathrm{L}^{-1} 1-\mathrm{MCP}$ for $0,15,30$, or $60 \mathrm{~s}$ in a factorial design. All fruit were ripened

179 immediately after treatment. No fruit were stored.

$180 \quad$ 2.3. Fruit quality assessments

181 Ethylene and $\mathrm{CO}_{2}$ production, skin color, and flesh firmness were measured every $3 \mathrm{~d}$ for a

182 maximum of $21 \mathrm{~d}$ in 2011, and $18 \mathrm{~d}$ in 2012 and 2013 on three replications of six fruits until the

183 firmness level decreased to an average of $\sim 13 \mathrm{~N}$ which was considered fully ripe.

184 2.3.1 Measurement of firmness and color

185 Flesh firmness was measured using a Fruit Texture Analyzer (GS-14, Güss Manufacturing Ltd.,

186 Strand, Western Cape, South Africa) fitted with an 8-mm diameter probe to penetrate the flesh to

187 a depth of $5 \mathrm{~mm}$ on opposite sides of each fruit after removing a 1-mm diameter section of skin.

188 Skin color was determined on opposite sides of each fruit using a Minolta colorimeter (Model

189 CR-400, Ramsey, N.Y., USA) and described using the L*, a* and b* color space. The hue angle

$190\left(\mathrm{~h}^{\circ}\right)$ represented the change in skin color from green $\left(120 \mathrm{~h}^{\circ}\right)$ to yellow $\left(60 \mathrm{~h}^{\circ}\right)$, calculated using

191 the formula $\operatorname{arctg}\left(b^{*} / a^{*}\right)$.

192 2.3.2. Measurement of ethylene and $\mathrm{CO}_{2}$ production 
193 Six fruit were placed into a 3.8 L glass jar as one replication, with three replications per

194 evaluation. After the jars were sealed for $60 \mathrm{~min}$ at $20^{\circ} \mathrm{C}$, a headspace sample was withdrawn

195 with a $10 \mathrm{~mL}$ syringe and subjected to analysis by gas chromatography (AGC Series 400;

196 Chandler Engineering Company, Tulsa, OK, USA) with a flame ionization detector and alumina

197 column for ethylene measurement. The ethylene concentration was calculated relative to a gas

198 standard. A second headspace sample was analyzed for $\mathrm{CO}_{2}$ with an infrared $\mathrm{CO}_{2}$ analyzer

199 (Horiba VIA-510; Horiba Instruments Inc., Irvine, CA) operated in a flow-through mode of 100

$200 \mathrm{~mL} \mathrm{~min}^{-1}$ with $\mathrm{N}_{2}$ as the carrier gas. The $\mathrm{CO}_{2}$ concentration was calculated relative to a certified

201 standard (Matheson Tri-Gas, Inc.) containing $0.25 \% \mathrm{CO}_{2}$ balance $\mathrm{N}_{2}$.

\subsection{Data analysis}

203 Statistical differences between treatment means were determined by the least significant

204 difference test (LSD) using analysis of variance (ANOVA). The $P$-value was used to determine

205 the level of significance $(P=0.05, P=0.01$ and $P=0.001)$ of the main effects of harvest,

206 treatment, dip time and the interactions of harvest $\mathrm{x}$ treatment and harvest $\mathrm{x}$ dip time. Firmness

207 and color data were also subjected to ANOVA and LSD means separation (Tukey test with $P=$

2080.05 significance level) to identify the significant differences between treatments. A comparative

209 analysis (t-test) of the regression equation slopes was applied to some data items to compare fruit

210 changes over time. A Pearson correlation analysis $(P=0.05)$ was performed to study the skin

211 color change in relation to pear softening. Statistical analyses were performed using the

212 statistical software XL-Stat (Addinsoft SARL, 2014). 
217 In all three years, liquid 1 -MCP treatment concentration had a highly significant $(P<0.0001)$

218 effect on the rate of fruit ripening. The dip time was also significant $(\mathrm{P}<0.001)$ in all years and

219 harvests, but with a lower level of significance in late harvests $(P<0.05)$. The fruit harvest date

220 significantly affected the ripening response in all years and locations $(P<0.001)$, but there were

221 no significant differences between mid- and late-harvests for most of the concentrations applied.

222 The levels of internal ethylene at harvest in early-harvested Sacramento fruit differed by $0.261 \pm$

$2230.07 \mu \mathrm{L} \mathrm{L}^{-1}$ among years, ranging from $0.018 \pm 0.007 \mu \mathrm{L} \mathrm{L}^{-1}$ in 2012 to $0.262 \pm 0.09 \mu \mathrm{L} \mathrm{L}^{-1}$ in

2242011 (data not shown). There was a significant interaction between 1-MCP concentration and

225 harvest $(P<0.0001)$ and 1 -MCP concentration and dip time $(P<0.0001)$.

226 3.1. Experiment 1: gaseous versus liquid 1-MCP

227 Both gaseous and liquid 1-MCP treatments delayed flesh softening and thereby extended the

228 shelf life of early-, mid- and late-harvested Sacramento (Fig. 1) and Lakeport (data not shown)

229 fruit. A $60 \mathrm{~s}$ postharvest dip in $1000 \mu \mathrm{g} \mathrm{L}{ }^{-1}$ liquid $1-\mathrm{MCP}$ at $29-38^{\circ} \mathrm{C}$ delayed Sacramento pear

230 fruit softening by $>15 \mathrm{~d}$ compared to the control fruit, while a 24 hour exposure to $0.6 \mu \mathrm{L} \mathrm{L}^{-1}$

231 gaseous $1-\mathrm{MCP}$ at $0{ }^{\circ} \mathrm{C}$ delayed softening by up to $15 \mathrm{~d}$ (Fig. 1). Similar results were observed

232 for Lakeport fruit (data not shown). A comparative analysis ( $t$-test) of regression slopes showed

233 that the softening process in pears treated with liquid and gaseous 1-MCP was not significantly

234 different for mid-harvest Sacramento (softening rates 2.64 and $3.05 \mathrm{~N} \mathrm{~d}^{-1}$, liquid and gaseous

235 treatments, respectively) and all Lakeport harvests (average softening rates 2.46 and $2.60 \mathrm{~N} \mathrm{~d}^{-1}$,

236 liquid and gaseous treatments, respectively). However, early and late-harvested fruit from the

237 Sacramento orchard treated with liquid 1-MCP remained firmer/were slower to soften $(P<0.05)$ 
238 than gaseous 1-MCP-treated fruit. After 5-weeks of storage at $1{ }^{\circ} \mathrm{C}$, the fruit ripening response 239 was similar to matching sets of fruit that were treated with ethylene after 1-MCP (Fig. 1 D-F). In 240 Lakeport, the only significant difference between gaseous and liquid 1-MCP-treated fruit was in 241 late-harvested fruit, which remained significantly firmer when treated with liquid 1-MCP (data 242 not shown). 
Fig. 1. Experiment 1. Firmness (N) of 'Bartlett' pears during ripening at $20{ }^{\circ} \mathrm{C}$ following treatment with liquid or gaseous 1-methylcyclopropene

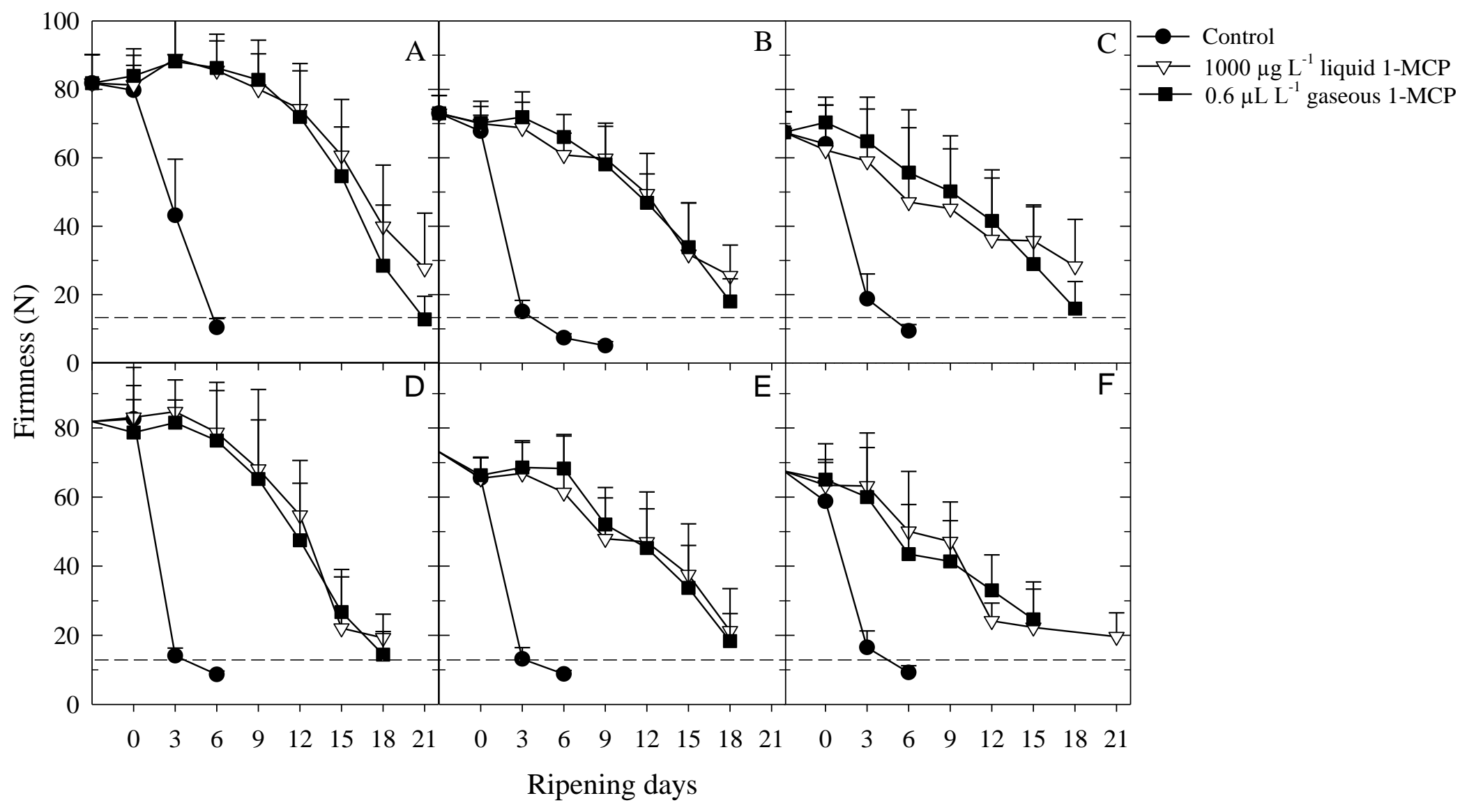


249 Pear skin yellowing was delayed $(P<0.05)$ during ripening in non-stored fruit treated with

250 liquid 1-MCP compared to gaseous 1-MCP in both locations and all harvests except early-

251 harvested Lakeport fruit, and also compared to control fruit in both locations and all harvests

252 except early-harvested Sacramento and late-harvested Lakeport fruit (data not shown). The

253 average skin $\mathrm{h}^{\circ}$ after $21 \mathrm{~d}$ of ripening was $100.4 \pm 2.1 \mathrm{~h}^{\circ}$ for liquid-1-MCP-treated fruit (not

254 fully-ripe), $97.9 \pm 3.0 \mathrm{~h}^{\circ}$ for gaseous-1-MCP treated fruit (fully-ripe) and $96.7 \pm 4.2 \mathrm{~h}^{\circ}$ for

255 control fruit (fully-ripe). There were no significant differences between the average skin color for

256 gaseous 1-MCP-treated and control fruit when the fruit were fully-ripe $(P<0.05)$. After storage,

257 pear skin yellowing was also delayed $(P<0.05)$ in the liquid-1-MCP-treated fruit compared to

258 both gaseous 1-MCP-treated fruit and control fruit in early-harvested Sacramento fruit and mid-

259 and late-harvested Lakeport fruit. (The average $h^{\circ}$ after $21 \mathrm{~d}$ of ripening was $95.2 \pm 1.4 \mathrm{~h}^{\circ}$ for

260 liquid 1-MCP-treated fruit (not fully-ripe), $92.4 \pm 2.2 \mathrm{~h}^{\circ}$ for gaseous 1-MCP-treated fruit (fully-

261 ripe) and $93.8 \pm 3.0 \mathrm{~h}^{\circ}$ for control fruit (fully ripe).

262 Both gaseous and liquid 1-MCP treated fruit similarly delayed and reduced rates of ethylene

263 production at $20^{\circ} \mathrm{C}$ compared to the control fruit in Sacramento (Fig. 2A-C). The results for

264 Lakeport fruit were very similar (data not shown). However, ethylene production by gaseous 1-

265 MCP-treated fruit started increasing before the liquid 1-MCP-treated fruit in most harvests.

266 Liquid 1-MCP-treated fruit showed increases in ethylene production after 15 and $8 \mathrm{~d}$ for early-

267 and late-harvested fruit, respectively, compared to after 12 and $8 \mathrm{~d}$ or 3 and $0 \mathrm{~d}$ for early- and

268 late-harvested fruit treated with gaseous 1-MCP or untreated (control), respectively. After

269 storage, ethylene production was higher in fruit from all harvests and locations relative to the

270 rates when fruit were ripened at harvest (Fig. 2D-F). At early-harvest, gaseous 1-MCP-treated

271 fruit showed increases in ethylene production after $13 \mathrm{~d}$ of ripening compared to after 16 or $0 \mathrm{~d}$ 
272 for liquid 1-MCP-treated or untreated fruit, respectively. At late-harvest, fruit treated with liquid 273 and gaseous 1-MCP started to produce ethylene after $16 \mathrm{~d}$. In both harvests, gaseous 1-MCP

274 produced more ethylene than liquid 1-MCP-treated fruit $\left(0.042 \mathrm{uL} \mathrm{kg}^{-1} 2^{-1}\right.$ higher for early and 275 late harvests, on average).

276

277 
Fig. 2. Experiment 1. Ethylene production $\left(\mathrm{uL} \mathrm{kg}^{-1} \mathrm{~s}^{-1}\right)$ of 'Bartlett' pears during ripening at $20^{\circ} \mathrm{C}$ following treatment with liquid or gaseous 1 279 methylcyclopropene (year 2011). Vertical lines represent the standard deviation of the mean ( \pm S.D., $n=18$ ). A-B-C corresponds to early, mid and 280 late harvests from Sacramento, respectively, without storage. D-E-F corresponds to early, mid and late harvests from Sacramento, respectively, 281 after 5-weeks storage at $1{ }^{\circ} \mathrm{C}$.

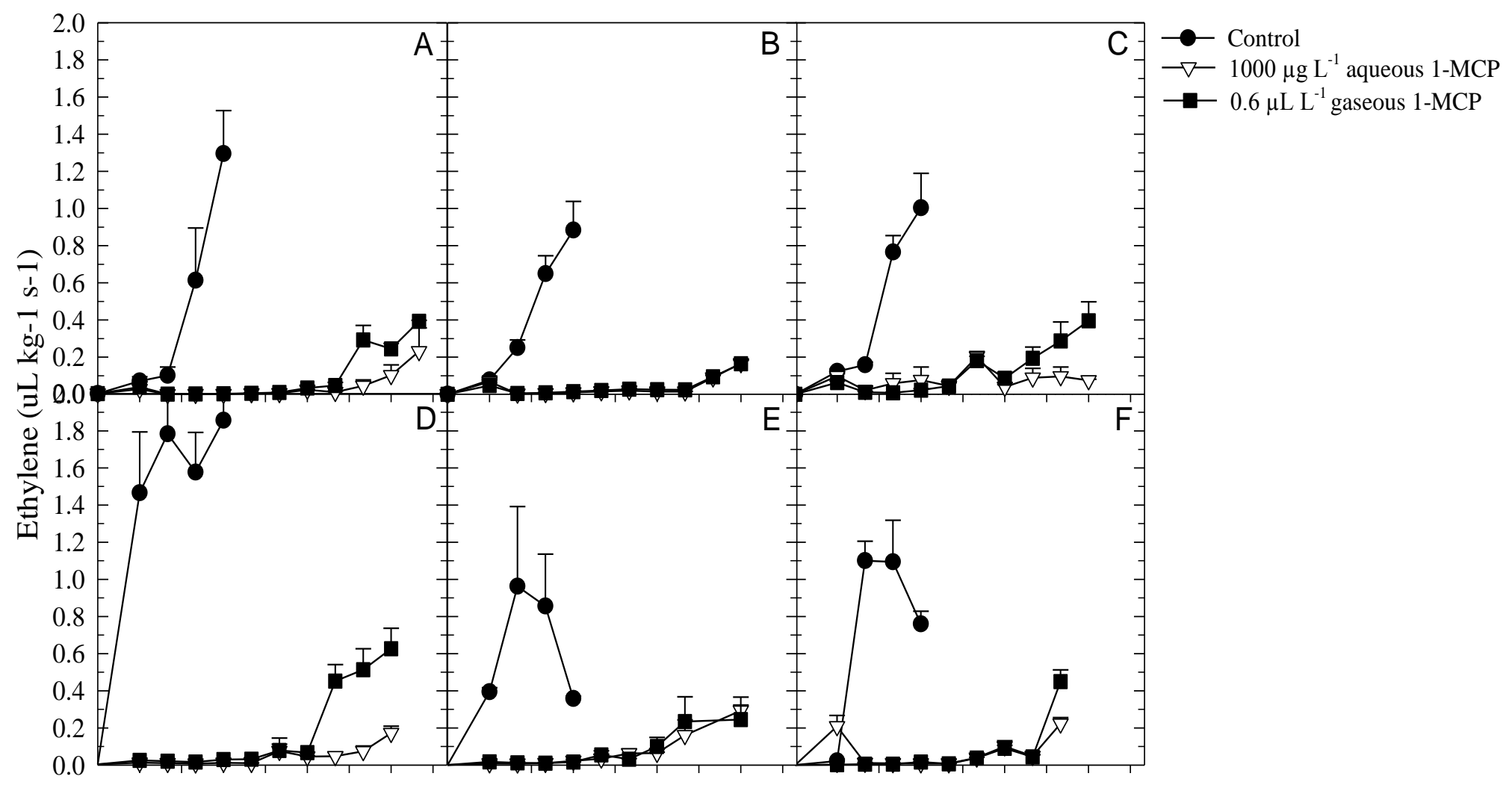

$\begin{array}{llllllllllllllllllllllll}0 & 3 & 6 & 9 & 12 & 15 & 18 & 21 & 0 & 3 & 6 & 9 & 12 & 15 & 18 & 21 & 0 & 3 & 6 & 9 & 12 & 15 & 18 & 21\end{array}$

Ripening days 
284 A decrease in respiration rate was also observed in gaseous- and liquid-1-MCP-treated fruit 285 compared to the control fruit in all harvests and locations (data not shown). Respiration rates of 286 liquid-1-MCP treated fruit were significantly lower than gaseous-1-MCP treated fruit in late287 harvested fruit from both Sacramento and Lakeport after $12 \mathrm{~d}$ of ripening $(P<0.001)$. After 288 storage, differences in respiration rate between gaseous- and liquid-1-MCP treatments were 289 significant $(P<0.001)$ in early-harvested fruit from both Sacramento and Lakeport.

\subsection{Experiment 2: liquid 1-MCP concentration effects}

291 The rate of fruit softening was dependent on the 1-MCP concentration applied during the $60 \mathrm{~s}$ 292 dip treatments (Fig.3), delaying ripening for a minimum of 12 days in relation to the control.

293 Fruit treated with $250 \mu \mathrm{g} \mathrm{L}^{-1}$ showed the least inhibition, becoming nearly fully ripe after $18 \mathrm{~d}$ at $29420{ }^{\circ} \mathrm{C}$ in all harvests. In general, those fruit treated with $\geq 500 \mu \mathrm{g} \mathrm{L}^{-1} 1-\mathrm{MCP}$ softened more

295 slowly, but fruit responded slightly differently depending on the harvest maturity. The

296 comparative analysis (t-test) of regression slopes showed that $750 \mu \mathrm{g} \mathrm{L}^{-1}$ was as effective as 1000

$297 \mu \mathrm{g} \mathrm{L}^{-1}$ in early-harvested Lakeport fruit, and mid- and late-harvested Sacramento fruit, while 500 $298 \mu \mathrm{g} \mathrm{L}^{-1}$ was also similar to $1000 \mu \mathrm{g} \mathrm{L}^{-1}$ in early- and late-harvested Sacramento fruit $(P<0.05)$.

299 Therefore, for early and late-harvested fruit from Sacramento, treatment with $500 \mu \mathrm{g} \mathrm{L}{ }^{-1} 1-\mathrm{MCP}$ 300 saturated the response, while for mid-harvested fruit from Sacramento and early harvested fruit 301 from Lakeport, $750 \mu \mathrm{g} \mathrm{L}^{-1}$ 1-MCP was needed to saturate the response. Mid- and late-harvested 302 Lakeport fruit were not evaluated in this experiment. 
Fig. 3. Experiment 2. Firmness (N) of 'Bartlett' pears during ripening at $20^{\circ} \mathrm{C}$ following treatment with liquid 1-methylcyclopropene for $60 \mathrm{~s}$ (year 2012). Vertical lines represent the standard deviation of the means ( \pm S.D., $n=18)$. A-B-C corresponds to early, mid and late harvests from

305 Sacramento, respectively, and D corresponds to early harvested fruit from Lakeport. Legend indicates aqueous 1-MCP concentrations $\left(\mu \mathrm{L} \mathrm{L}^{-1}\right)$.

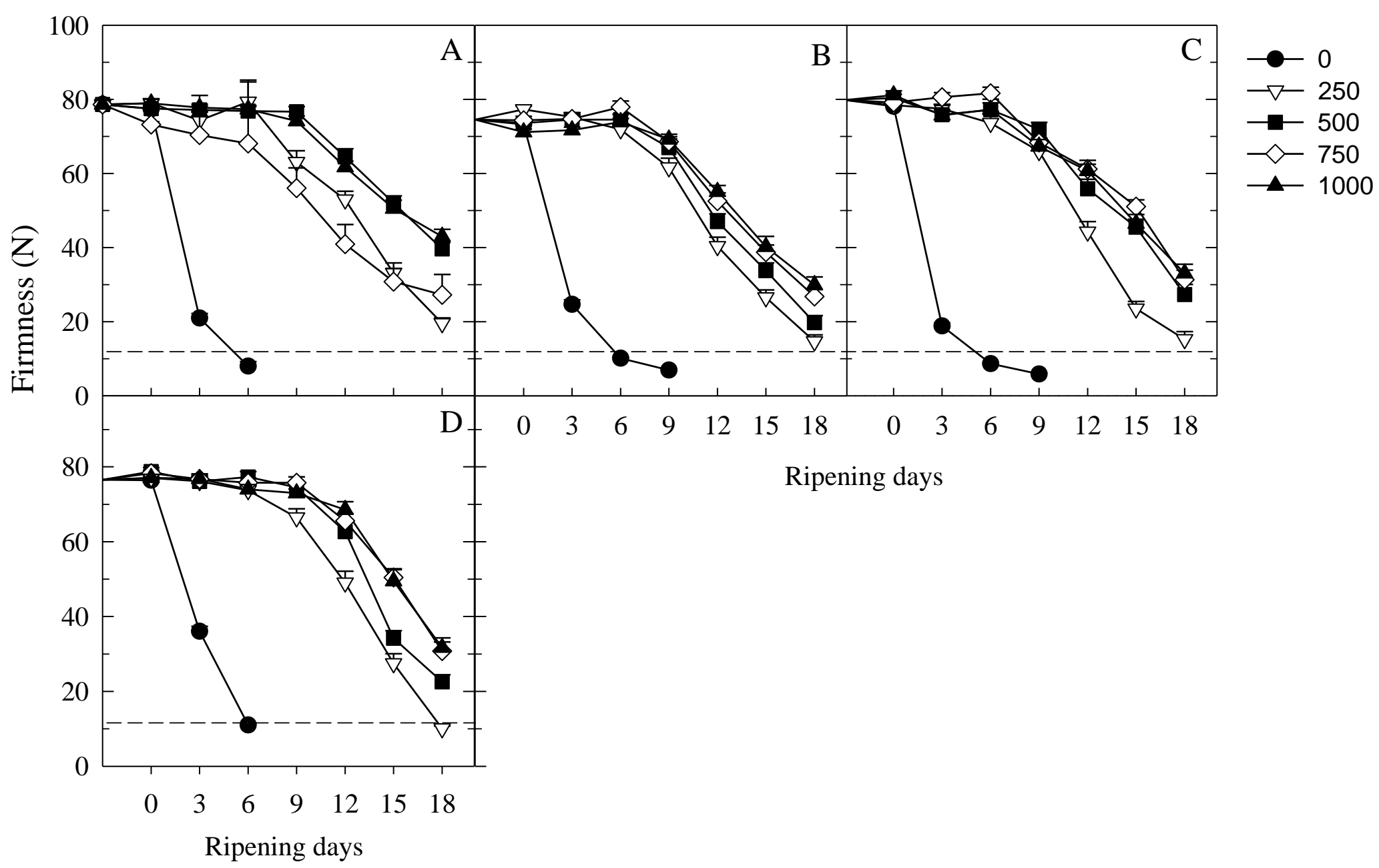


1-MCP treatment concentrations were correlated to color development; after $18 \mathrm{~d}$ of ripening,

309 yellow skin color development was correlated to fruit firmness in treated-fruit of Sacramento

310 harvests $(\mathrm{P}<0.0001$ early and mid-harvests, $\mathrm{P}<0.01$ late harvest $)$ and early Lakeport harvest

311 ( $\mathrm{P}<0.0001)$ (data not shown). Early harvested Sacramento and Lakeport fruit treated with 250

312 (nearly fully-ripe), 500 and $750 \mu \mathrm{g} \mathrm{L}^{-1}$ (not fully-ripe) liquid 1-MCP were more yellow (from

31388.4 to $99.3 \mathrm{~h}^{\circ}$ and 91.3 to $95.7 \mathrm{~h}^{\circ}$, Sacramento and Lakeport, respectively) after $18 \mathrm{~d}$ of

314 ripening than the control fruit (fully-ripe) $\left(107.8 \mathrm{~h}^{\circ}\right.$ Sacramento, and $96.5 \mathrm{~h}^{\circ}$ Lakeport $)(\mathrm{P}<0.05)$.

315 Mid- and late-harvested fruit treated with $250 \mu \mathrm{g} \mathrm{L}^{-1}$ 1-MCP were more yellow (92.1 and 90.7

$\left.316 \mathrm{~h}^{\circ}\right)$ than the control fruit $\left(92.6\right.$ and $\left.91.8 \mathrm{~h}^{\circ}\right)$ when they were all fully-ripe $(\mathrm{P}<0.05)$.

317 All concentrations of liquid 1-MCP reduced ethylene production relative to the control fruit (data

318 not shown). However, fruit treated with $250 \mu \mathrm{g} \mathrm{L}^{-1} 1-\mathrm{MCP}$ were differentiated from the other

319 treatments for their early (on average $3 \mathrm{~d}$ earlier than fruit treated with $\geq 500 \mu \mathrm{g} \mathrm{L}^{-1}$ ) and higher

320 (> 2-fold) production rate of ethylene. Ethylene production from early-harvested Sacramento

321 fruit treated with $\geq 500 \mu \mathrm{g} \mathrm{L}^{-1} 1-\mathrm{MCP}$ behaved similarly (started to increase after $\sim 12 \mathrm{~d}$, with the

322 same production rate during ripening) to fruit treated with $250 \mu \mathrm{g} \mathrm{L}^{-1} 1-\mathrm{MCP}$. In the remaining

323 harvests, fruit treated with $\geq 500 \mu \mathrm{g} \mathrm{L}^{-1} 1$-MCP started to increase in ethylene production after

$324 \sim 15 \mathrm{~d}$, and the production rates increased accordingly with the concentration; $500 \mu \mathrm{g} \mathrm{L}{ }^{-1} 1-\mathrm{MCP}$

325 treated-fruit always showed higher ethylene production than $1000 \mu \mathrm{g} \mathrm{L}^{-1} 1$-MCP treated-fruit, but

326 for fruit treated with $750 \mu \mathrm{g} \mathrm{L}^{-1} 1-\mathrm{MCP}$, it depended on the harvest.

327 All liquid 1-MCP concentrations reduced fruit respiration rate relative to the control fruit;

328 however, respiration rate was less affected by treatment concentration than ethylene production

329 (data not shown). In agreement with the ethylene production data, the highest respiration rate

330 corresponded to the $250 \mu \mathrm{g} \mathrm{L}^{-1} 1$-MCP treatment in early- and mid-harvested Sacramento fruit, 
331 but only early-harvested Lakeport fruit treated with $250 \mu \mathrm{g} \mathrm{L} \mathrm{L}^{-1} 1-\mathrm{MCP}$ showed significant

332 differences with respect to the other treatments $(\mathrm{P}<0.001)$.

\section{3.3 Experiment 3: liquid 1-MCP dip time effects}

334 To investigate the minimum dip time required for liquid 1-MCP treatment, a low concentration

335 of 1-MCP $\left(250 \mu \mathrm{g} \mathrm{L}^{-1}\right)$ was selected, so as not to overwhelm the response, and tested on mid-

336 and late-harvested Lakeport fruit. Dip time had a significant $(\mathrm{P}<0.001)$ effect on the rate of fruit

337 softening; the fruit dipped for 60 and 45 s took an additional 3 days to ripen compared to fruit

338 dipped for 15 and $30 \mathrm{~s}$ (Fig. 4). The same effect was observed in both mid- and late-harvested 339 fruit. 
341 Fig. 4. Experiment 3. Firmness (N) of 'Bartlett' pears during ripening at $20^{\circ} \mathrm{C}$ following treatment with $250 \mu \mathrm{g} \mathrm{L} \mathrm{L}^{-1}$ liquid 1 -methylcyclopropene 342 (year 2012). Vertical lines represent the standard deviation of the means ( \pm S.D., $n=18$ ). A and B correspond to mid- and late-harvests from 343 Lakeport, respectively. Legend indicates different dip times (s).

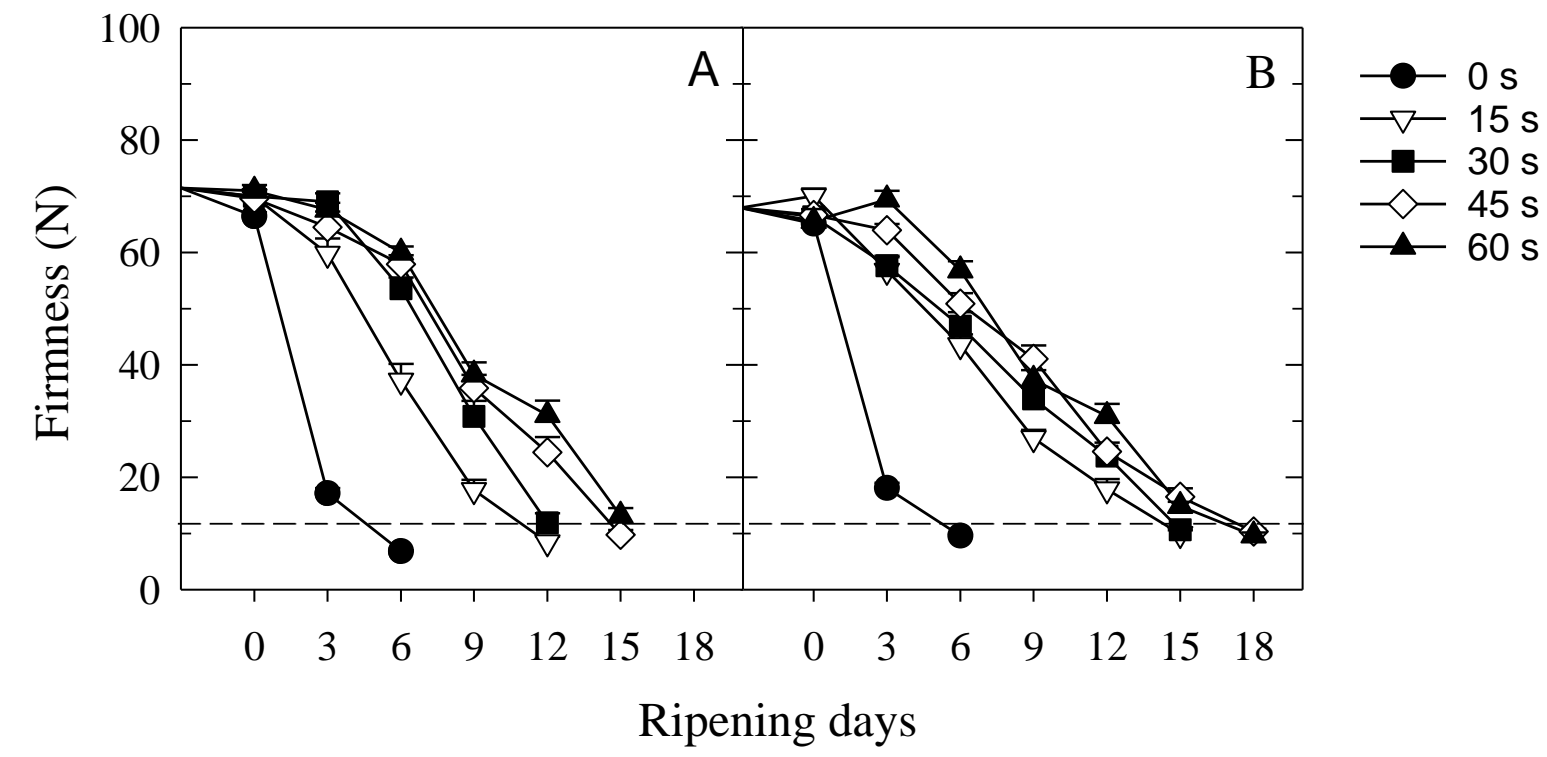


346 However, pear softening was not significantly correlated to pear fruit color after $18 \mathrm{~d}$ of ripening.

347 For mid-harvest, all the dipping-times except $30 \mathrm{~s}$ showed the same fruit color (average $93.5 \pm$

$\left.3481.4 \mathrm{~h}^{\circ}\right)$ and were more yellow than the control fruit $\left(97.3 \mathrm{~h}^{\circ}\right)(\mathrm{P}<0.05)$; in late-harvested fruit

349 there were no color differences between any treated or control fruit (average $92.3 \pm 1.1 \mathrm{~h}^{\circ}$ ).

350 All dip times reduced ethylene production relative to the control fruit (data not shown). Fruit

351 dipped for $15 \mathrm{~s}$ were differentiated from the other treatments for their earlier $(3 \mathrm{~d}$ earlier than 30 ,

35245 and $60 \mathrm{~s}$ ) and higher production rate of ethylene (consistently $\sim 0.16 \mathrm{uL} \mathrm{kg}^{-1} \mathrm{~s}^{-1}$ higher) during

353 ripening. All liquid 1-MCP dipping times reduced fruit respiration rate relative to the control

354 fruit (data not shown); however, comparative analysis (t-test) of regression slopes showed that

355 dip time had no significant influence on respiration rate.

\subsection{Experiment 4: liquid 1-MCP concentration $x$ dip time interaction}

357 Across all harvests and locations, higher 1-MCP concentrations led to greater reductions in the 358 rate of softening; and when fruit were treated with the same concentration, longer dipping times

359 further reduced the rate of softening (Fig. 5).Treatment efficacy was a function of concentration

360 and time. For example, dipping pears from the Sacramento orchard in $250 \mu \mathrm{g} \mathrm{L}{ }^{-1} 1$-MCP for 60

$361 \mathrm{~s}$ was statistically as effective as dipping pears in $500 \mu \mathrm{g} \mathrm{L}-1$ for 15 and $30 \mathrm{~s}(P<0.05$; Table 1).

362 The same effect was observed with higher concentrations of 1-MCP. Dipping pears in $500 \mu \mathrm{g} \mathrm{L}$

$363{ }^{1} 1$-MCP for $60 \mathrm{~s}$ was as effective at slowing softening as dipping fruit in $1000 \mu \mathrm{g} \mathrm{L}^{-1}$ for $30 \mathrm{~s}$ in

364 all harvests and locations and dipping for $60 \mathrm{~s}$ in early-and late-harvested Sacramento and

365 Lakeport pears (Table 1). In late-harvested Lakeport fruit, there was no significant difference in

366 firmness after $18 \mathrm{~d}$ of ripening between fruit dipped for 15,30 or $60 \mathrm{~s}$ in $1000 \mu \mathrm{g} \mathrm{L}{ }^{-1}$ and for 30

367 or $60 \mathrm{~s}$ in $500 \mu \mathrm{g} \mathrm{L}^{-1}$, as determined by comparing the regression slopes (data not shown) and 
368 ANOVAs (Table 1). Overall, fruit firmness after $18 \mathrm{~d}$ of ripening was higher in Sacramento fruit 369 (ranging from 8.4 to $38.0 \mathrm{~N}$ ) than in Lakeport fruit (from 8.0 to $30.7 \mathrm{~N}$ ).

370

371

372

373

374

375

376

377

378

379

380

381

382

383

384

385 
Fig. 5. Experiment 4. Firmness (N) of 'Bartlett' pears during ripening at $20^{\circ} \mathrm{C}$ following treatment with various concentrations of liquid 1methylcyclopropene for various dip times (year 2013). Vertical lines represent the standard deviation of the means $( \pm$ S.D., $n=18)$. A-B-C corresponds to fruit from Sacramento early, mid and late season, respectively, and D-E-F to early, mid and late harvests from Lakeport, respectively). Legend indicates aqueous 1-MCP concentration $\left(\mu \mathrm{g} \mathrm{L}^{-1}\right)-$ immersion duration (s).

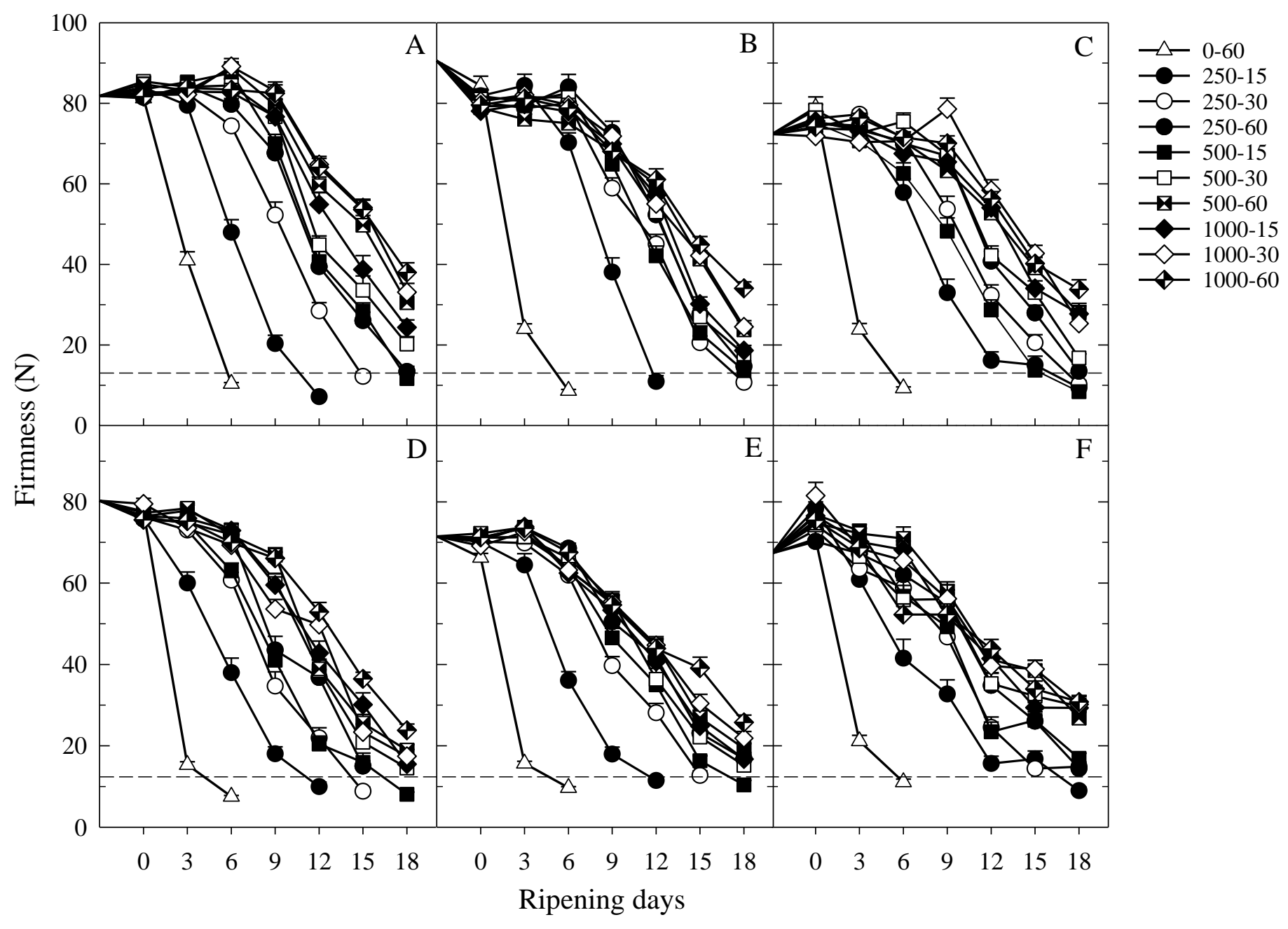


391 Table 1. Experiment 4. Firmness of 'Bartlett' pears after treatment with liquid 1-methylcyclopropene 392 followed by $18 \mathrm{~d}$ of ripening at $20^{\circ} \mathrm{C}$ (fully ripe $<13 \mathrm{~N}$ ).

\begin{tabular}{|c|c|c|c|c|c|c|c|}
\hline \multirow{3}{*}{$\begin{array}{c}1-\mathrm{MCP} \\
\left(\mu \mathrm{g} \mathrm{L}^{-1}\right)\end{array}$} & \multirow{3}{*}{$\begin{array}{c}\text { Immersion } \\
(\mathrm{s})\end{array}$} & \multicolumn{6}{|c|}{ Firmness $(\mathrm{N})$} \\
\hline & & \multicolumn{3}{|c|}{ Sacramento } & \multicolumn{3}{|c|}{ Lakeport } \\
\hline & & Early & Mid & Late & Early & Mid & Late \\
\hline 0 & 60 & $<13 \mathrm{e}$ & $<13 \mathrm{de}$ & $<13 \mathrm{~d}$ & $<13 d$ & $<13 \mathrm{e}$ & $<13 \mathrm{c}$ \\
\hline \multirow[t]{3}{*}{250} & 15 & $<13 \mathrm{e}$ & $<13 \mathrm{de}$ & $<13 d$ & $<13 d$ & $<13 \mathrm{e}$ & $<13 \mathrm{c}$ \\
\hline & 30 & $<13 \mathrm{e}$ & $<13 \mathrm{de}$ & $<13 \mathrm{~d}$ & $<13 d$ & $<13 \mathrm{e}$ & $14.8 \mathrm{bc}$ \\
\hline & 60 & $13.4 \mathrm{de}$ & $14.7 \mathrm{~cd}$ & $13.5 \mathrm{~cd}$ & $<13 \mathrm{~d}$ & $16.7 \mathrm{bcd}$ & $14.4 \mathrm{bc}$ \\
\hline \multirow[t]{3}{*}{500} & 15 & $<13 \mathrm{e}$ & $13.6 \mathrm{cde}$ & $<13 \mathrm{~d}$ & $<13 d$ & $<13 \mathrm{e}$ & $16.9 \mathrm{~b}$ \\
\hline & 30 & $20.2 \mathrm{~cd}$ & $17.8 \mathrm{c}$ & $16.7 \mathrm{c}$ & $14.5 \mathrm{bc}$ & $15.2 \mathrm{cde}$ & $29.7 \mathrm{a}$ \\
\hline & 60 & $30.5 \mathrm{ab}$ & $23.7 \mathrm{~b}$ & $27.9 \mathrm{ab}$ & $18.9 \mathrm{ab}$ & $19.3 \mathrm{bc}$ & $26.7 \mathrm{a}$ \\
\hline \multirow[t]{3}{*}{1000} & 15 & $24.3 \mathrm{bc}$ & $18.6 \mathrm{bc}$ & $27.7 \mathrm{ab}$ & $15.5 \mathrm{~b}$ & $16.7 \mathrm{bcd}$ & $29.3 \mathrm{a}$ \\
\hline & 30 & $33.1 \mathrm{a}$ & $24.5 \mathrm{~b}$ & $25.3 \mathrm{~b}$ & $17.4 \mathrm{~b}$ & $21.8 \mathrm{ab}$ & $30.1 \mathrm{a}$ \\
\hline & 60 & $38.0 \mathrm{a}$ & $34.1 \mathrm{a}$ & $33.8 \mathrm{a}$ & $23.7 \mathrm{a}$ & $25.7 \mathrm{a}$ & $30.7 \mathrm{a}$ \\
\hline
\end{tabular}

Values within columns followed by the same letter are not significantly different at $\mathrm{P}=0.05$ (ANOVA-

394 Tukey test).

395

Pear skin color changes from green to yellow were delayed in a dependent manner with 1-MCP

397 treatment concentration, but dipping times had a much smaller effect on color in most treatments

398 and harvests (Table 2). After $18 \mathrm{~d}$ of ripening, all Sacramento treated fruit showed high

399 correlations between color and firmness (coefficients $0.48 P<0.0001,0.71 P<0.0001$ and $0.64 P$

$400<0.0001$ for early, mid- and late-harvest, respectively). When correlations were analyzed

401 separately by dipping time and concentration, concentration had higher correlation coefficients

402 (average $0.67 P<0.0001$ ) than dipping times (average $0.27 P<0.01$ ). Fully-ripe Sacramento

403 fruit previously treated with $250 \mu \mathrm{g} \mathrm{L}^{-1}$ for 15 and $30 \mathrm{~s}$ and $500 \mu \mathrm{g} \mathrm{L}^{-1}$ for $15 \mathrm{~s}$ were more yellow

404 that the fully-ripe control fruit in all harvests $(P<0.05)$. After $18 \mathrm{~d}$ of ripening, fruit treated with

$405250 \mu \mathrm{g} \mathrm{L}^{-1}$ for $60 \mathrm{~s}$ and $500 \mu \mathrm{g} \mathrm{L}^{-1}$ for $30 \mathrm{~s}$ (both not fully softened) were also more yellow than

406 the fully-ripe control fruit $(P<0.05)$. Likewise for mid-harvested Lakeport fruit, all

407 concentrations and dip times resulted in yellower fruit than the control fruit after $18 \mathrm{~d}$ of 
408 ripening. However, almost all late-harvested Lakeport fruit presented the same color as the

409 control $(P<0.05$; Table 2).

410 Table 2. Experiment 4. Skin color (hue angle $\left(\mathrm{h}^{\circ}\right)$ ), of 'Bartlett' pears when fully-ripe or after $18 \mathrm{~d}$ 411 ripening, whichever occurred first, following treatment with liquid 1-methylcyclopropene.

\begin{tabular}{|c|c|c|c|c|c|c|c|}
\hline \multirow{3}{*}{$\begin{array}{c}1-\mathrm{MCP} \\
\left(\mu \mathrm{g} \mathrm{L}^{-1}\right)\end{array}$} & \multirow{3}{*}{$\begin{array}{c}\text { Immersion } \\
\text { (s) }\end{array}$} & \multicolumn{6}{|c|}{ Hue angle $\left(\mathrm{h}^{\circ}\right)$} \\
\hline & & \multicolumn{3}{|c|}{ Sacramento } & \multicolumn{3}{|c|}{ Lakeport } \\
\hline & & Early & Mid & Late & Early & Mid & Late \\
\hline 0 & 60 & $99.5 \mathrm{ab}$ & $98.1 \mathrm{~b}$ & $96.6 \mathrm{ab}$ & $96.5 \mathrm{a}$ & $96.8 \mathrm{a}$ & $94.5 \mathrm{a}$ \\
\hline \multirow[t]{3}{*}{250} & 15 & $92.5 \mathrm{e}$ & $94.2 \mathrm{def}$ & $91.7 \mathrm{~d}$ & $94.4 \mathrm{bcd}$ & $93.5 \mathrm{~cd}$ & $91.9 \mathrm{ab}$ \\
\hline & 30 & $91.8 \mathrm{e}$ & 92.7 ef & $92.3 \mathrm{~d}$ & $93.0 \mathrm{de}$ & - & $92.0 \mathrm{ab}$ \\
\hline & 60 & $93.5 \mathrm{de}$ & $92.5 \mathrm{f}$ & $92.4 \mathrm{~d}$ & $93.1 \mathrm{de}$ & $92.5 \mathrm{~d}$ & $90.0 \mathrm{~b}$ \\
\hline \multirow[t]{3}{*}{500} & 15 & $91.3 \mathrm{e}$ & 92.9 ef & $91.4 \mathrm{~d}$ & $92.5 \mathrm{e}$ & $92.7 \mathrm{~cd}$ & $92.2 \mathrm{ab}$ \\
\hline & 30 & $96.0 \mathrm{~cd}$ & $94.3 \mathrm{def}$ & $93.2 \mathrm{~cd}$ & 93.4 cde & $92.7 \mathrm{~cd}$ & $93.9 \mathrm{a}$ \\
\hline & 60 & $97.8 \mathrm{bc}$ & $96.1 \mathrm{bcd}$ & $94.9 \mathrm{bc}$ & 93.9 bcde & $93.2 \mathrm{~cd}$ & $93.2 \mathrm{ab}$ \\
\hline \multirow[t]{3}{*}{1000} & 15 & $95.5 \mathrm{~cd}$ & 94.9 cde & $95.2 \mathrm{~b}$ & $94.2 \mathrm{bcd}$ & $92.5 \mathrm{~d}$ & $94.0 \mathrm{a}$ \\
\hline & 30 & $99.2 \mathrm{ab}$ & 97.1 bc & $96.0 \mathrm{ab}$ & $95.4 \mathrm{ab}$ & $93.8 \mathrm{c}$ & $93.3 \mathrm{ab}$ \\
\hline & 60 & $100.7 \mathrm{a}$ & $100.5 \mathrm{a}$ & $97.4 \mathrm{a}$ & $94.8 \mathrm{abc}$ & $95.1 \mathrm{~b}$ & $93.7 \mathrm{a}$ \\
\hline
\end{tabular}

412 Values within columns followed by the same letter are not significantly different at $P=0.05$ (ANOVA-

413 Tukey test). Hue angle of $120^{\circ}$ corresponds to green skin; the closer to $60^{\circ}$, the more yellow the fruit.

414

415 When pear fruit were dipped for shorter times using the same 1-MCP concentration, ethylene

416 production started to increase earlier during ripening in both Sacramento and Lakeport fruit

417 (Fig.6, only Sacramento results shown). Fruit dipped in $250 \mu \mathrm{g} \mathrm{L}^{-1}$ 1-MCP for $15 \mathrm{~s}$ showed a

418 sharp increase in ethylene production $3 \mathrm{~d}$ earlier than fruit dipped in the same concentration for

$41930 \mathrm{~s}$, and $6 \mathrm{~d}$ earlier than fruit dipped for $60 \mathrm{~s}$. Fruit from the early-harvest in Sacramento dipped

420 in $500 \mu \mathrm{g} \mathrm{L}^{-1} 1-\mathrm{MCP}$ for $15 \mathrm{~s}$ showed a sharp increase in ethylene production sooner and

421 produced higher levels of ethylene $\left(1.07 \pm 0.23 \mathrm{uL} \mathrm{kg}^{-1} \mathrm{~s}^{-1}\right)$ than fruit dipped in $250 \mu \mathrm{g} \mathrm{L} \mathrm{L}^{-1} 1$ -

422 MCP for $60 \mathrm{~s}(0.84 \pm 0.19 \mathrm{uL} / \mathrm{kg} \mathrm{h})$. Similarly, mid-harvested Sacramento and early-and late-

423 harvested Lakeport (data not shown) fruit dipped in $1000 \mu \mathrm{g} \mathrm{L} \mathrm{L}^{-1} 1-\mathrm{MCP}$ for $15 \mathrm{~s}$ showed higher

424 ethylene production than fruit treated with $500 \mu \mathrm{g} \mathrm{L}^{-1} 1-\mathrm{MCP}$ for $30 \mathrm{~s}$. The differences in 
425 ethylene production rates and number of days to the sharp increase in ethylene production as

426 related to dip times were smaller when fruit were treated with 500 or $1000 \mu \mathrm{g} \mathrm{L}^{-1} 1-\mathrm{MCP}$ than

427 for the $250 \mu \mathrm{g} \mathrm{L}^{-1} 1$-MCP treatment. Within a concentration, once ethylene production started

428 increasing, the rate of ethylene production was related to dip times; shorter dip time, higher

429 ethylene production rate.

430

431

432

433

434

435

436

437

438

439

440

441

442 
443

444

445

446

447
Fig. 6. Experiment 4. Ethylene production $\left(\mathrm{uL} \mathrm{kg}^{-1} \mathrm{~s}^{-1}\right)$ and respiration rate $\left(\mathrm{mL} \mathrm{kg}^{-1} \mathrm{~s}^{-1}\right)$ of 'Bartlett' pears during ripening at $20{ }^{\circ} \mathrm{C}$ following treatment with various concentrations of liquid 1-methylcyclopropene for various dip times (year 2013). The vertical lines represent the standard deviation of the means ( \pm S.D., $n=18)$. A-B-C corresponds to early, mid and late harvests from Sacramento, respectively. Legend indicates aqueous 1-MCP concentration ( $\left.\mu \mathrm{g} \mathrm{L}^{-1}\right)$ - dipping time (s).

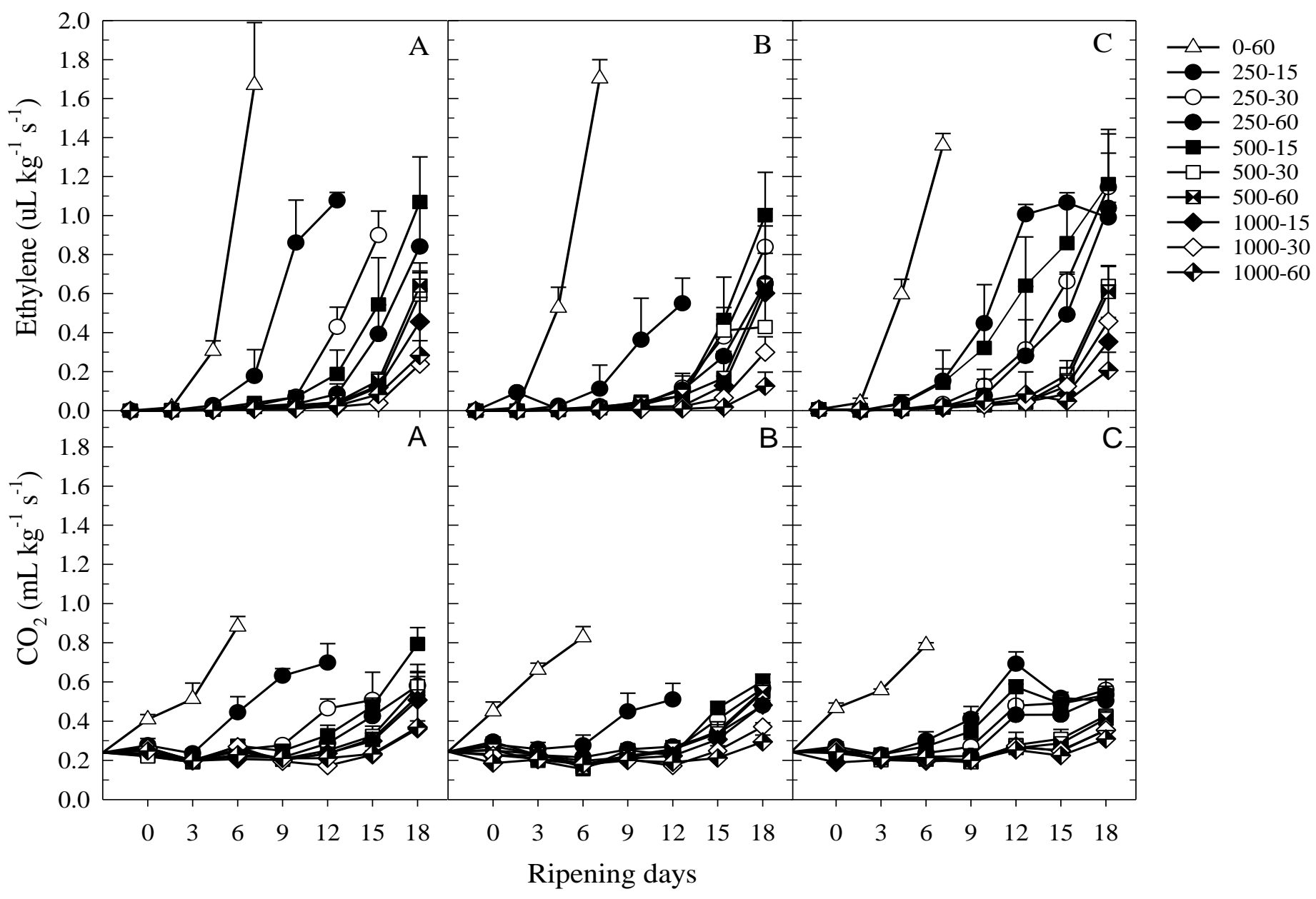


449 The increase in respiration rate of the 1-MCP treated fruit from all treatments was evidently

450 delayed and in most cases the respiration rate was lower than the control fruit (Fig. 6 D-F,

451 Sacramento results). In early- and mid-harvested Sacramento and Lakeport fruit, treatment with

$452250 \mu \mathrm{g} \mathrm{L}^{-1} 1-\mathrm{MCP}$ for 15 and $30 \mathrm{~s}$ resulted in significantly different respiration rates as compared

453 with the other treatments, with earlier increases in respiration rate. Overall, the respiration rates

454 of fruit treated at different concentrations and dip times were more divergent in early- and mid-

455 season fruit. In late-harvested fruit, respiration rates were lower (showing very low rates in

456 Lakeport; data not shown) and very similar between treatments.

\subsection{Interactions: concentration $x$ dip time $x$ harvest $x$ year (data not shown)}

458 Across the three years of study, pear fruit from Sacramento and Lakeport were treated with 1000

$459 \mu \mathrm{g} \mathrm{L} \mathrm{L}^{-1}$ liquid 1-MCP for $60 \mathrm{~s}$ allowing a comparison across seasons. ANOVAs of 2011, 2012 460 and 2013 outcomes showed that for this concentration of 1-MCP, there were no differences in 461 early-, mid- and late-harvested fruit firmness after 18 days of ripening among the three years $(P$

$462<0.001)$. Other 1-MCP concentrations and dip times showed significant differences between

463 years. Early-harvest fruit treated with $250 \mu \mathrm{g} \mathrm{L}^{-1}$ liquid 1-MCP for $60 \mathrm{~s}$ in 2012 showed

464 differences in firmness after $18 \mathrm{~d}$ of ripening from fruit similarly treated in $2013(P<0.001)$, but

465 mid- and late-harvested fruit firmness was not different between the two years where this

466 concentration and dip time was applied $(P<0.001)$. Dipping pears for $15 \mathrm{~s}$ in $250 \mu \mathrm{g} \mathrm{L}{ }^{-1}$ liquid

467 1-MCP gave consistent firmness after $18 \mathrm{~d}$ of ripening in 2012 and 2013 (P < 0.001 ). 
471 Our results showed that applying liquid formulations of 1-MCP in 'Bartlett' pears delayed

472 softening and reduced ethylene production in fruit from different harvest dates. In general, the

473 liquid formulation at $1000 \mu \mathrm{g} \mathrm{L}^{-1}$ for $60 \mathrm{~s}$ was slightly more efficacious than exposure to $0.6 \mu \mathrm{L}$

$474 \mathrm{~L}^{-1} \mathrm{MCP}$ gas for $24 \mathrm{~h}$. According to Macnish et al. (2012), late-harvested 'Bartlett' pear fruit

475 usually produce higher levels of ethylene at harvest, and this could be the reason for the

476 difficulties found by researchers and producers to consistently delay ripening of pear fruit from

477 late harvests with gaseous 1-MCP, since ethylene could interfere with 1-MCP binding to the

478 ethylene receptors (Calvo and Sozzi, 2009; Ekman et al., 2004; Macnish et al., 2012; Trinchero

479 et al., 2004; Villalobos-Acuña et al., 2011a, 2011b). Our results showed that liquid 1-MCP was

480 very effective as an ethylene action inhibitor in all harvests, including late-harvested 'Bartlett'

481 pears (which averaged 50x more ethylene production than mid-harvested pears) across the three

482 years of our study. Our results showed an equal or superior efficacy of liquid 1-MCP treatments

483 in more mature 'Bartlett' pear fruit compared to less mature fruit, in contrast to the reduced

484 response in more mature fruit that has been reported previously for gaseous 1-MCP treatments

485 (Chiriboga et al., 2013; Gamrasni et al., 2010; Jung and Watkins, 2014; Macnish et al., 2012;

486 Mir et al., 2001; Villalobos-Acuña et al., 2011a, b; Wang and Sugar, 2015; Watkins, 2008).

487 The inhibitory effects of gas and liquid 1-MCP were only slightly reduced when fruit were stored

488 for 5 weeks at $1^{\circ} \mathrm{C}$, indicating a lasting effect of both treatments at low temperatures.

489 Comparable results between gaseous and liquid 1-MCP applications have also been observed in

490 tomato and avocado (Choi et al., 2008; Choi and Huber, 2008), and liquid formulations have also

491 proved to be effective in breaker and turning tomatoes (Choi and Huber, 2008) and plums 
492 (Manganaris et al., 2008). To the best of our knowledge, this is the first report of postharvest 493 application of liquid 1-MCP and comparison between gaseous and liquid 1-MCP formulations in 494 'Bartlett' pear.

495 The liquid 1-MCP formulation was effective in a concentration- and dip time-dependent manner. 496 Ethylene and respiration followed the same trends as softening; higher concentrations of 1-MCP 497 delayed the increase in and rates of ethylene production and respiration significantly more than 498 lower concentrations, and these results match previous research with liquid 1-MCP performed on 499 tomatoes and avocados (Choi et al., 2008) and plums (Manganaris et al., 2008). Choi and Huber 500 (2008) also found that liquid 1-MCP was effective on tomato after immersion times as brief as $50115 \mathrm{~s}$, in agreement with our data.

502 Concentrations of 250,500 or $1000 \mu \mathrm{g} \mathrm{L}^{-1} 1-\mathrm{MCP}$ could be used to treat 'Bartlett' pears after 503 harvest depending on the intended shelf life. Fruit treated for $15-30 \mathrm{~s}$ with $250 \mu \mathrm{g} \mathrm{L}{ }^{-1}$ liquid 1$504 \mathrm{MCP}$ were able to ripen in less than $18 \mathrm{~d}$ in all years, harvests and locations, extending shelf life 505 for a minimum of $5 \mathrm{~d}$ beyond the control fruit. Treatment with $500 \mu \mathrm{g} \mathrm{L}^{-1}$ liquid 1-MCP 506 extended shelf-life for a minimum of $10 \mathrm{~d}$ (15 s dip time) beyond the control fruit across years 507 and locations. Treatment with $1000 \mu \mathrm{g} \mathrm{L}{ }^{-1}$ liquid 1-MCP gave the longest shelf life, independent 508 of the dip time (treated fruit did not ripen before $18 \mathrm{~d}$ ). Ripening of these fruit was very slow, but 509 not irreversibly impaired, in contrast to the strong and irreversible effects sometimes reported 510 after gaseous 1-MCP treatments in 'Bartlett' pear (Ekman et al., 2004; Villalobos-Acuña and 511 Mitcham, 2008) and in 'd'Anjou' pear (Chen and Spotts, 2006) .

512 Our results indicate that low liquid 1-MCP concentrations with longer dip times were more 513 effective to suppress softening, respiration rate and ethylene production than higher 
514 concentrations with shorter dip times. These results confirm what Choi and Huber (2008)

515 suggested about the mechanism by which the liquid formulation delivers biologically active

516 levels of 1-MCP to the receptors. They hypothesized that saturating concentrations of 1-MCP

517 would provide molecules in excess of those necessary to saturate all ethylene receptors while low

518 concentrations applied for longer times would maximize binding to ethylene receptors, and

519 hence the treatment efficacy.

520 Most of the fruit from both locations and all harvests dipped in $500 \mu \mathrm{g} \mathrm{L}{ }^{-1}$ liquid 1-MCP for 15

521 or $30 \mathrm{~s}$ ripened before or around $18 \mathrm{~d}$. For practical use with 'Bartlett' pears, application of 500

$522 \mu \mathrm{g} \mathrm{L}^{-1}$ liquid 1-MCP with short controlled dip durations could be the best approach to delay

523 fruit ripening in a controlled manner without overly inhibiting the ripening process. The dipping

524 duration would be the key to determine the rate of fruit ripening; a difference of $\pm 15 \mathrm{~s}$ would

525 delay/advance ripening by $3 \mathrm{~d}$ in early harvested fruit and $2 \mathrm{~d}$ in mid and late harvested fruit. The

526 optimum protocol would depend on commercial facilities; shorter dip times could be

527 advantageous in facilities with a high volume of production while longer dip times would reduce

528 the effect of variance in dip times under commercial practice.

529 The response of 'Bartlett' pear fruit to gaseous 1-MCP-treatment has been reported to be highly

530 variable from harvest to harvest and year to year (unpublished data; AgroFresh, Inc., personal

531 communication). Our data compares for the first time postharvest application of liquid 1-MCP in

532 consecutive years. Fruit treated with liquid 1-MCP $\left(1000 \mu \mathrm{g} \mathrm{L}{ }^{-1}\right)$ gave a consistent response year

533 to year, but remained dependent on harvest maturity and growing location. For example, all

534 early-harvested fruit from the same growing location that were treated with liquid 1-MCP

535 softened similarly in 2011, 2012 and 2013. Similar results were observed for mid- and late-

536 harvested fruit. However, this consistency depended on the concentration applied; lower 
537 concentrations $\left(250-500 \mu \mathrm{g} \mathrm{L}^{-1}\right)$ resulted in more variable effects on the rate of softening

538 between years for early-harvested fruit, while fruit from mid- and late-harvest showed similar

539 rates of softening among the years. This may be related to the fact that in some years, early

540 harvested fruit produced measureable ethylene and in other years they did not, while mid- and

541 late-harvested fruit always produce some ethylene at harvest. Differences in the fruit stage of

542 maturity at harvest could have a more significant impact on 1-MCP treatment efficacy at lower

543 concentrations. These results also suggest that the maturity of the fruit does have an effect

544 independent of the accumulation of ethylene in the headspace competing with 1-MCP, which

545 could indicate the importance of monitoring ethylene concentrations in treatment rooms before

546 applying 1-MCP, as suggested by Macnish (2012).

547 In our studies, treated fruit skin yellowing was significantly linked to fruit softening; high

548 treatment concentrations resulted in firmer and less yellow fruit than those treated with low

549 concentrations after the same number of days of ripening. Similar results were observed by Choi

550 and Huber (2008) with tomato and Manganaris et al., (2008) with avocado. Villalobos-Acuña et

551 al. (2011a, 2011b) reported that application of $0.3 \mu \mathrm{L} \mathrm{L}^{-1}$ gaseous 1-MCP also delayed yellow

552 skin color development along with firmness during ripening, and when fruit were fully-ripe,

553 treated and untreated fruit were the same color. However, in our study, fully-ripe fruit pears that

554 had been treated with liquid 1-MCP were more yellow than fully-ripe control fruit in all

555 locations, harvests and years. Moreover, most of the fruit treated with 500-1000 $\mu \mathrm{g} \mathrm{L}{ }^{-1}$ liquid 1-

556 MCP after $18 \mathrm{~d}$ of ripening (not fully-ripe yet), were also visibly more yellow than fully-ripe

557 control fruit. Our results suggest that liquid 1-MCP treatment enhances color development in

558 'Bartlett' pear fruit. This effect could be a misleading indicator of ripeness for the pear industry

559 and consumers. This differential ripening effect has been shown before in 1-MCP treated 
560 bananas (Golding et al., 1998). It presumably reflects different sensitivities between ethylene-

561 dependent skin coloration and flesh softening. Further study is required to unravel the

562 biochemical and molecular factors that link the ethylene signal transduction pathway in liquid 1-

563 MCP-treated fruit and the chlorophyll degradation pathway.

564

565

566

567

568

569

570

571

572

573

574

575

576

577 
579 Application of 1-MCP as a liquid could be a useful alternative to gaseous application of this

580 ethylene action inhibitor to 'Bartlett' pear fruit after harvest. Treatment with liquid 1-MCP

581 across a range of concentrations and dip times delayed pear ripening in all harvests, including

582 late-harvested pears, across the three years of our study. Dipping in $1000 \mu \mathrm{g} \mathrm{L}{ }^{-1}$ liquid 1-MCP

583 for $60 \mathrm{~s}$ was the most consistent treatment among years and locations; however, the time required

584 to ripen the fruit at $20^{\circ} \mathrm{C}$ could be too long for some commercial applications. Treatment at 500

$585 \mu \mathrm{g} \mathrm{L}^{-1}$ liquid 1-MCP is recommended for 'Bartlett' pears as this dose slows the ripening process, 586 and provides a consistent response among years and locations for mid- and late-harvested fruit.

587 Application of liquid 1-MCP is fast and easy and does not require a sealed room. However, 588 challenges could arise in preventing off-gassing and loss of active ingredient from the solution.

589 Careful control of dip time will also be important for some applications. In addition, to achieve

590 storage benefits, fruit would need to be dipped in bins or run over a packing line and re-binned

591 before storage. For the commercial benefits to be realized, further research and treatment

592 refinement will be necessary to overcome these challenges. 
600 We thank the USDA Specialty Crops Research Initiative Grant (\#2009-51181-05783) and

601 California Pear Advisory Board for financial support, and Greene \& Hemly, Inc., Courtland, CA,

602 Stillwater Orchards, Courtland, CA, and Scully Packing Co. LLC, Finley, CA, for providing the

603 fruit for this study.

604

605

606

607

608

609

610

611

612

613

614

615

616 
618 Agar, I.T., Biasi, W.V., Mitcham, E.J., 2000. Cold storage duration influences ethylene

619 biosynthesis and ripening of 'Bartlett' pears. HortScience 35, 687-690.

620 Argenta, L.C., Krammes, J.G., Megguer, C.A., Amarante, C.V.T., Mattheis, J., 2003. Ripening 621 and quality of 'Laetitia' plums following harvest and cold storage as affected by inhibition 622 of ethylene action. Pes. Agropec. Bras. 38, 1139-1148.

623 Baritelle, A.L., Hyde, G.M., Fellman, J.K., Varith, J., 2001. Using 1-MCP to inhibit the

Byers, R.E., Carbaugh, D.H., Combs, L.D., 2005. Ethylene inhibitors delay fruit drop, maturity, and increase fruit size of 'Arlet' apples. HortScience 40, 2061-2065.

628 Calvo, G., Sozzi, G.O., 2004. Improvement of post-harvest storage quality of 'Red Clapp's' pears by treatment with 1-methylcyclopropene at low temperature. J. Hortic. Sci. Biotech. 79,

631 Calvo, G., Sozzi, G.O., 2009. Effectiveness of 1-MCP treatments on 'Bartlett' pears as influenced by the cooling method and the bin material. Postharvest Biol. Technol. 51, 49930-934.

634 Chen, P.M., Mellenthin, W.M., 1981. Effects of harvest date on ripening capacity and postharvest life of 'd'Anjou' pears. J. Am. Soc. Hortic. Sci. 106, 695-698. 55. after storage. Int. J. Fruit Sci. 5, 3-18. 
638 Chiriboga, M.A., Schotsmans, W.C., Larrigaudière, C., Dupille, E., Recasens, L., 2013.

639 Responsiveness of 'Conference' pears to 1-methylcyclopropene; the role of harvest date,

640 orchard location and year. J. Sci. Food Agric. 93, 619-625.

641 Choi, S.T., Huber, D.J., 2008. Influence of aqueous 1-methylcyclopropene concentration,

642 immersion duration, and solution longevity on the postharvest ripening of breaker-turning

643 tomato (Solanum lycopersicum L.) fruit. Postharvest Biol. Technol. 49, 147-154.

644 Choi, S.T., Tsouvaltzis, P., Lim, C.I., Huber, D.J., 2008. Suppression of ripening and induction

645 of asynchronous ripening in tomato and avocado fruits subjected to complete or partial

646 exposure to aqueous solutions of 1-methylcyclopropene. Postharvest Biol. Technol. 48,

$647 \quad 206-214$.

648 DeEll, J.R., Murr, D.P., Porteus, M.D., Rupasingue, H.P.V., 2002. Influence of temperature and

649 duration of 1-methylcyclopropene (1-MCP) treatment on apple quality. Postharvest Biol.

650 Technol. 24, 349-353.

651 DeEll, J., Ehsani-Moghaddam, B., 2011. Timing of postharvest 1-methylcyclopropene treatment

652 affects Bartlett pear quality after storage. Can. J. Plant Sci. 91, 853-858.

653 Defilippi, B.G., Manríquez, D., Robledo, P., 2010. Use of 1-methylcyclopropene (1-MCP) as a

654 strategy to improve post-harvest life of 'Abate Fetel' pears. In XI International Pear

$655 \quad$ Symposium 909, 739-744.

656 Ekman, J.H., Clayton, M., Biasi, W.V., Mitcham, E. J., 2004. Interactions between 1-MCP

657 concentration, treatment interval and storage time for 'Bartlett' pears. Postharvest Biol.

$658 \quad$ Technol. $31,127-136$ 
Elfving, D.C., S.R. Drake, A.N. Reed, Visser, D.V., 2007. Preharvest applications of sprayable 1-methylcyclopropene in the orchard for management of apple harvest and postharvest condition. HortScience 42, 1192-1199.

Gamrasni, D., Ben-Arie, R., Goldway, M., 2010. 1-Methylcyclopropene (1-MCP) application to Spadona pears at different stages of ripening to maximize fruit quality after storage. Postharvest Biol. Technol. 58, 104-112.

Golding, J. B., Shearer, D., Wyllie, S. G., McGlasson, W. B., 1998. Application of 1-MCP and propylene to identify ethylene-dependent ripening processes in mature banana fruit. Postharvest Biol. Technol. 14, 87-98.

Guillén, F., Castillo, S., Zapata, P. J., Martinez-Romero, D., Serrano, M., Valero, D., 2007. Efficacy of 1-MCP treatment in tomato fruit: 1. Duration and concentration of 1-MCP treatment to gain an effective delay of postharvest ripening. Postharvest Biol. Technol. 43, 23-27.

Hansen, E., 1943. Relation of ethylene production to respiration and ripening of premature pears. In: Proc. Am. Soc. Hort. Sci 43, 69-72.

Hiwasa, K., Kinugasa, Y., Amano, S., Hashimoto, A., Nakano, R., Inaba, A., Kubo, Y., 2003. Ethylene is required for both the initiation and progression of softening in pear (Pyrus communis L.) fruit. J. Exp. Bot. 54, 771-779.

Jung, S.K., and Watkins, C.B., 2014. Internal ethylene concentrations in apple fruit at harvest affect persistence of inhibition of ethylene production after 1-methylcyclopropene treatment. Postharvest Biol Technol. 96, 1-6. 
Klee, H.J., 2004. Ethylene signal transduction. Moving beyond Arabidopsis. Plant Physiol. 135, 660-667.

Kubo, Y., Hiwasa, K., Owino, W.O., Nakano, R., Inaba, A., 2003. Influence of time and concentration of 1-MCP application on the shelf life of pear 'La France' fruit. HortScience 38, 1414-1416.

Manenoi, A., Bayogan, E.R.V., Thumdee, S., Paull, R.E., 2007. Utility of 1-methylcyclopropene as a papaya postharvest treatment. Postharvest Biol. Technol. 44, 55-62.

Manganaris, G.A., Crisosto, C.H., Bremer, V., and Holcroft, D., 2008. Novel 1methylcyclopropene immersion formulation extends shelf life of advanced maturity 'Joanna Red' plums (Prunus salicina Lindell). Postharvest Biol. Technol. 47, 429-433.

Mir, N.A., Curell, E., Khan, N., Whitaker, M., Beaudry, R.M., 2001. Harvest maturity, storage temperature, and 1-MCP application frequency after firmness retention and chlorophyll fluorescence of 'Redchief Delicious' apples. J. Am. Soc. Hortic. Sci. 126, 618-624.

McArtney, S.J., Obermiller, J.D, Schupp, J.R., Parker, M.L., Edgington, T.B., 2008. Preharvest 1-methylcyclopropene delays fruit maturity and reduces softening and superficial scald of apples during long-term storage. HortScience 43, 366-371. 'Bartlett' pears in transit to improve ripening and quality. Washington State University 
Tree Fruit Research and Extension Center. Postharvest Information Network. http://postharvest.tfrec.wsu.edu/pgDisplay.php?article=PC2000I (accessed 19.09.15)

703

704

705

706

707

708

709

710

Mwaniki, M.W., Mathooko, F.M., Matsuzaki, M., Hiwasa, K., Tateishi, A., Ushijima, K., Ryohei, N., Akitsugu, I., Kubo, Y., 2005. Expression characteristics of seven members of the $\beta$-galactosidase gene family in 'La France'pear (Pyrus communis L.) fruit during growth and their regulation by 1-methylcyclopropene during postharvest ripening. Postharvest Biol. Technol. 36, 253-263.

Nock, J.F., Watkins, C.B., James, H., Reed, N., Oakes, R.L., 2009. Preharvest application of 1methylcyclopropene (1-MCP) to control fruit drop of apples, and its effects on postharvest quality. In: VI International Postharvest Symposium 877, 365-374.

Pongprasert, N., Srilaong, V., 2014. A novel technique using 1-MCP microbubbles for delaying postharvest ripening of banana fruit. Postharvest Biol. Technol. 95, 42-45.

Puig, L., Varga, D.M., Chen, P.M., Mielke, E.A., 1996. Synchronizing ripening in individual 'Bartlett' pears with ethylene. HortTechnology 6, 24-27.

Sisler, E.C., Serek, M., 2003. Compounds interacting with the ethylene receptor in plants. Plant Biol. 5, 473-480.

Sisler, E.C., 2006. The discovery and development of compounds counteracting ethylene at the receptor level. Biotechnol. Adv. 24, 357-367.

Trinchero, G.D., Sozzi, G.O., Covatta, F., Fraschina, A.A., 2004. Inhibition of ethylene action by 1-methylcyclopropene extends postharvest life of "Bartlett" pears. Postharvest Biol. Technol. 32, 193-204. 
722 Villalobos-Acuña, M., Mitcham, E. J., 2008. Ripening of European pears: the chilling dilemma.

723 Postharvest Biol. Technol. 49, 187-200.

724 Villalobos-Acuña, M.G., Biasi, W.V., Flores, S., Mitcham, E.J., Elkins, R.B., Willits, N.H., 725 2010. Preharvest application of 1-methylcyclopropene influences fruit drop and storage 726 potential of 'Bartlett'pears. HortScience 45, 610-616.

727 Villalobos-Acuña, M.G., Biasi, W.V., Flores, S., Jiang, C.Z., Reid, M.S., Willits, N.H., Mitcham, 728 E.J., 2011a. Effect of maturity and cold storage on ethylene biosynthesis and ripening in 729 'Bartlett'pears treated after harvest with 1-MCP. Postharvest Biol. Technol. 59, 1-9.

730 Villalobos-Acuña, M.G., Biasi, W.V., Mitcham, E.J., Holcroft, D., 2011b. Fruit temperature and 731 ethylene modulate 1-MCP response in 'Bartlett' pears. Postharvest Biol. Technol. 60, 17732

733 Wang, Y., Sugar, D., 2015. 1-MCP efficacy in extending storage life of 'Bartlett' pears is 734 affected by harvest maturity, production elevation, and holding temperature during 735 treatment delay. Postharvest Biol. Technol. 103, 1-8.

736 Watkins, C.B., 2008. Overview of 1-methylcyclopropene trials and uses for edible horticultural 737 crops. HortScience 43, 86-94.

738 Yuan, R., Carbaugh, D.H., 2007. Effects of NAA, AVG, and 1-MCP on ethylene biosynthesis, 739 preharvest fruit drop, fruit maturity, and quality of 'Golden Supreme' and 'Golden 740 Delicious’ apples. HortScience 42, 101-105. 
741 Zhang, Z., Huber, D.J., Hurr, B.M., Rao, J., 2009. Delay of tomato fruit ripening in response to

742 1-methylcyclopropene is influenced by internal ethylene levels. Postharvest Biol.

$743 \quad$ Technol. 54, 1-8.

744 Zhang, Z., Huber, D.J., Rao, J., 2010. Short-term hypoxic hypobaria transiently decreases

745 internal ethylene levels and increases sensitivity of tomato fruit to subsequent 1-

746 methylcyclopropene treatments. Postharvest Biol. Technol. 56, 131-137.

747 Zhang, Z., Huber, D.J., Rao, J., 2011. Ripening delay of mid-climateric avocado fruit in response

748 to elevated doses of 1-methylcyclopropene and hypoxia-mediated reduction in internal

749 ethylene concentration. Postharvest Biol. Technol. 60, 83-91.

750

751

752

753

754

755 
Efficacy of liquid 1-methylcyclopropene to delay ripening of 'Bartlett' pears

List of suggested referees and contact information

1. Dr. Randy Beaudry

Professor, College of Agriculture and Natural Resources

Department of Horticulture

Michigan State University, A22 Plant \& Soil Sciences Building, East Lansing, MI 48824-1325

Phone: (517) 355-5191

Fax: (517) 353-0890

E-mail: beaudry@msu.edu

\section{Dr. Christopher Watkins}

Professor, College of Agriculture and Natural Resources

Director, Cornell Cooperative Extension

356/127 Roberts Hall/Plant Science

Phone: (607) 255-8546

Email: chris.watkins@cornell.edu

\section{Dr. Jeffrey K. Brecht}

Professor, University of Florida

Horticultural Sciences Department

1217 Fifield Hall

Phone: 352-273-4778

E-mail: jkbrecht@ufl.edu

\section{Dr Jennifer DeEll}

Postharvest Physiologist

Ontario Ministry of Agriculture, Food and Rural Affairs

Phone: 519-426-1408 (Canada)

E-mail: jennifer.deell@omaf.gov.on.ca 